\title{
Hubungan Faktor Okupasi terhadap Aktivitas Asetilkolinesterase Eritrosit dan Fungsi Kognitif pada Petani yang Menggunakan Pestisida Organofosfat
}

\author{
Taufik Hidayatullah ${ }^{1}$, Melisa I. Barliana ${ }^{2,6}$, Bertha Pangaribuan ${ }^{3}$, Andi Wijaya ${ }^{4}$, \\ Sri A. Sumiwi2 ${ }^{2}$ Hanna Goenawan ${ }^{5}$ \\ 'Program Studi Magister Farmasi Klinik, Universitas Padjadjaran, Bandung, Indonesia,
} ${ }^{2}$ Fakultas Farmasi, Universitas Padjadjaran, Sumedang, Indonesia, ${ }^{3}$ PT. Prodia OHI International, Jakarta Pusat, Indonesia, ${ }^{4}$ PT. Prodia Widyahusada, Tbk., Jakarta Pusat, Indonesia,

${ }^{5}$ Fakultas Kedokteran, Universitas Padjadjaran, Sumedang, Indonesia, ${ }^{6}$ Pusat Unggulan Iptek

Perguruan Tinggi Inovasi Pelayanan Kefarmasian, Universitas Padjadjaran, Sumedang, Indonesia

\begin{abstract}
Abstrak
Organofosfat merupakan pestisida yang disukai oleh petani karena hasilnya terlihat jelas pada tanaman. Namun, pajanan organofosfat terhadap manusia dapat menimbulkan gangguan akut maupun kronis yang disebabkan sifat residunya. Untuk mengetahui pajanan pestisida pada manusia, dapat dilakukan biomonitoring dengan cara mengukur aktivitas enzim asetilkolinesterase (AChE) dalam darah. Cara organofosfat dalam menyebabkan efek toksik di antaranya dengan menghambat kerja enzim AChE. Enzim AChE yang terhambat menyebabkan proses pengiriman impuls saraf dapat mengalami gangguan, salah satunya gangguan fungsi kognitif. Tujuan penelitian ini adalah untuk mengetahui hubungan pajanan pestisida organofosfat terhadap aktivitas enzim AChE eritrosit dan fungsi kognitif pada petani. Metode penelitian ini menggunakan rancangan potong lintang dengan pendekatan observasi analitik. Sampel penelitian ini adalah 69 petani yang menggunakan pestisida organofosfat di daerah Lembang dan Pangalengan, Bandung. Data yang diambil berupa data karakteristik, aktivitas AChE eritrosit yang diambil dari sampel darah petani yang kemudian diukur dengan metode Ellman di laboratorium, dan fungsi kognitif menggunakan kuesioner Mini Mental State Examination. Hasilnya, diperoleh 26 responden (38\%) mengalami gangguan fungsi kognitif dan 43 responden (62\%) memiliki fungsi kognitif normal. Uji statistik menunjukkan faktor usia $(p=0,010)$, faktor pendidikan $(p=0,002)$ serta faktor okupasi durasi penyemprotan $(p=0,016)$ memiliki hubungan bermakna dengan fungsi kognitif. Faktor okupasi juga memiliki hubungan bermakna terhadap aktivitas asetilkolinesterase pada petani, yaitu faktor frekuensi penyemprotan $(p=0,035)$ dan faktor penggunaan alat pelindung diri (APD) $(\mathrm{p}=0,011)$. Simpulan pada penelitian ini adalah terdapat hubungan yang bermakna antara faktor okupasi terhadap aktivitas asetilkolinesterase eritrosit dan fungsi kognitif pada petani yang menggunakan pestisida organofosfat.
\end{abstract}

Kata kunci: AChE, asetilkolinesterase, kognitif, okupasi, organofosfat, pestisida

\section{Correlation of Occupation Factor on the Activities of Erytrocyt Acetylcholinesterase and Cognitive Function in Farmers Using Organophosphate Pesticide}

\begin{abstract}
Organophosphate is a pesticide preferred by farmers due to the clearly observed result in plants. However, the residual characteristics have been implicated in induced acute or chronic complications, following an exposure to humans. The extent is determined through biomonitoring, by measuring the activity of the enzyme acetylcholinesterase (AChE) in blood, which is inhibited by the toxic effect of organophosphate. In addition, there is a possibility of interference with the nerve impulse transmission, leading to impaired cognitive function. These are skills related to attention, memory, judgment, problem solving, and abilities in planning, monitoring and evaluating. The purpose of this study, therefore, was to determine the relationship of organophosphate pesticide exposure to erythrocyte AChE enzyme activity and cognitive function in farmers. Therefore, a cross-sectional design with analytical observational approach was employed, and the samples include 69 farmers using organophosphate pesticides in Lembang and Pangalengan, Bandung. The data collected comprised of individual characteristics, erythrocyte AChE activity in blood samples measured by Ellman method in the laboratory, and cognitive function using Mini Mental State Examination questionnaire. The results showed a total of 26 respondents (38\%) experiencing cognitive impairment, while $43(62 \%)$ had normal function. Based on statistical evaluation, age $(p=0.010)$, education $(p=0.002)$, and occupational duration of spraying $(\mathrm{p}=0.016)$ had significant relationship with cognitive function. Furthermore, the occupational factors also have a significant relationship with acetylcholinesterase activity, in the aspect of spraying frequency $(\mathrm{p}=0.035)$ and the use of personal protective equipment (PPE) $(\mathrm{p}=0.011)$. In conclusion, a substantial correlation was established between occupational factors on erythrocyte acetylcholineesterase activity and the cognitive function of farmers using organophosphate pesticides.
\end{abstract}

Keywords: Acethylcholinesterase, AChE, cognitive, occupation, organophosphate, pesticide

Korespondensi: Taufik Hidayatullah, M.Farm., Program Studi Magister Farmasi Klinik, Universitas Padjadjaran, Bandung, Jawa Barat 40161, Indonesia, email: tovics.h@yahoo.com

Naskah diterima: 29 Juli 2019, Diterima untuk diterbitkan: 7 Februari 2020, Diterbitkan: 29 Juni 2020 


\section{Pendahuluan}

Organofosfat saat ini masih menjadi pilihan utama yang digunakan oleh petani dalam memberantas hama tanaman. Selain karena direkomendasikan oleh Departemen Pertanian akibat mudah hilang/terurai di alam, juga karena organofosfat memiliki daya basmi yang kuat terhadap hama, efek yang cepat, dan hasilnya dapat terlihat dengan jelas dan baik pada tanaman. ${ }^{1}$ Namun, efek pajanan pestisida organofosfat pada manusia dapat menyebabkan keracunan akut maupun kronis akibat sifat residu pestisida organofosfat. Hasil dari penelitian-penelitian sebelumnya menyimpulkan bahwa penggunaan pestisida organofosfat di luar standar pemakaian akan menyebabkan keracunan dan gangguan sistem pada tubuh manusia. ${ }^{2}$ Organofosfat merupakan jenis pestisida yang paling banyak digunakan hampir di seluruh dunia terutama di sektor pertanian dan perkebunan sebagai salah satu cara memberantas hama. Sebagai substansi kimia, pestisida memberikan efek toksik bagi manusia yang terpapar. Data World Health Organization (WHO) tahun 2008 menyebutkan terdapat 346.000 kasus kematian yang disebabkan oleh keracunan pestisida yang tidak disengaja, dengan $66 \%$ di antaranya terjadi di negara berkembang. Di Indonesia, kasus kematian akibat keracunan pestisida akut diperkirakan mencapai 12.000 per tahun. ${ }^{1}$

Efek toksik dari pajanan organofosfat di antaranya dapat menyebabkan gangguan pada sistem pernafasan, fungsi hati, sistem kardiovaskuler, sistem saraf, sistem hormon, serta fungsi ginjal. Untuk dapat mengetahui besar pajanan pestisida pada tubuh manusia, dapat dilakukan biomonitoring dengan cara mengukur aktivitas enzim asetilkolinesterase (AChE) dalam darah. Salah satu cara kerja organofosfat dalam memberikan efek toksik ini yaitu dengan menghambat kerja $\mathrm{AChE}$ yang terdapat pada sistem saraf pusat di otak dan perifer. ${ }^{3}$ Selain pada neuromuscular junction, AChE juga ditemukan pada eritrosit. Penelitian telah menunjukkan bahwa terdapat korelasi yang positif antara kadar AChE darah dan tingkat toksisitas organofosfat. ${ }^{4}$ Chronic organophosphate induced neuropsychiatric disorders (COPIND) merupakan kumpulan gejala neuropsikiatri akibat pajanan kronik organofosfat. Gejala klinis yang paling sering muncul antara lain gangguan pada memori, konsentrasi dan proses belajar, depresi, gejala psikotik, kelelahan kronik, disfungi otonom dan gejala ekstrapiramidal seperti distonia, bradikenesia serta fungsi kognitif. ${ }^{4}$ Fungsi kognitif adalah suatu kemampuan atensi, daya ingat, pertimbangan, pemecahan masalah, dan kemampuan dalam perencanaan, penilaian, pengawasan dan melakukan evaluasi. Fungsi kognitif juga terkait dengan aktivitas mental yang dilakukan secara sadar seperti kemampuan berpikir, belajar dan penggunaan bahasa. $^{5}$

Dalam hasil penelitian yang dilakukan oleh Cinthya pada tahun 2019, diungkap bahwa sebanyak $75 \%$ dari 40 responden mengalami gangguan kognitif, dengan 57,5\% responden mengalami gangguan kognitif ringan dan $17,5 \%$ mengalami gangguan kognitif sedang pada petani bunga akibat pajanan pestisida ${ }^{6}$ Penelitian lain juga telah dilakukan mengenai gangguan kognitif pada pekerja yang terpapar pestisida, hasilnya $39,1 \%$ petani jeruk yang menggunakan pestisida mengalami gangguan kognitif ringan. ${ }^{6}$

Berdasarkan data-data di atas, peneliti ingin melakukan penelitian untuk mengetahui hubungan faktor okupasi terhadap aktivitas AChE eritrosit dan fungsi kognitif pada petani yang menggunakan pestisida organofosfat. Selain itu juga belum terdapat penelitian yang dilakukan mengenai hubungan faktor okupasi terhadap aktivitas AChE eritrosit dan fungsi kognitif pada petani yang menggunakan pestisida organofosfat. Keterbaruan penelitian ini yaitu pengukuran $\mathrm{AChE}$ dilakukan melalui 
eritrosit, bukan melalui serum atau plasma.

\section{Metode}

Penelitian ini menggunakan metode observasional analitik dengan rancangan potong lintang. Kelaikan etik penelitian ini telah diperoleh dari Komite Etik Penelitian Kesehatan Fakultas Kedokteran Universitas Padjadjaran dengan nomor 952/UN6.KEP/ EC/2019. Jumlah sampel yang diikutsertakan dalam penelitian ini adalah 69 sampel atau responden, ditentukan dari rumus besaran sampel yang data proporsi atau prevalensinya tidak diketahui, dan untuk mengantisipasi drop out dilakukan substitusi sebesar 10\%. Penelitian ini dilakukan pada bulan Juni-Juli 2019 di Perkebunan Tanaman Hias Lembang dan Perkebunan Sayur Pangalengan, Bandung, Jawa Barat.

Pemeriksaan terhadap aktivitas AChE eritrosit dilakukan di Industrial Toxicology Laboratory Prodia OHI dengan menggunakan alat spektrofotometri dengan metode Ellman yang diperoleh dari sampel darah petani sebanyak 12 cc di area siku dan pemeriksaan fungsi kognitif dilakukan dengan kuesioner Mini Mental State Examination (MMSE) yang sudah divalidasi dan menjadi referensi di Indonesia salah satunya oleh Kolegium Psikiatri Indonesia. Dalam hal ini, MMSE merupakan instrumen baku sehingga tidak dilakukan uji validitas dan reliabilitasnya. Pengumpulan data lainnnya seperti identitas atau karakteristik responden, faktor risiko okupasi dan lainnya menggunakan kuesioner. Data hasil penelitian diolah menggunakan program SPSS versi 25 untuk dilakukan analisis secara univariat, bivariat maupun multivariat hubungan tiap-tiap variabel.

\section{Hasil}

Hasil pengolahan data berdasarkan Tabel 1 menunjukkan karakteristik responden pada subjek penelitian, antara lain untuk kategori usia, responden termuda adalah 21 tahun dan yang tertua adalah 59 tahun dengan rata-rata usia 42 tahun. Rata-rata masa kerja responden adalah 17 tahun dengan masa kerja paling singkat 1 tahun dan paling lama adalah 37 tahun. Jenjang pendidikan responden paling tinggi adalah Sekolah Menengah Atas (SMA) berjumlah 31 responden (45\%) dan paling rendah Sekolah Dasar (SD) berjumlah 38 responden (55\%). Sebanyak 62 responden mengaku merokok, dengan jumlah responden yang telah merokok kurang dari 10 tahun yaitu 8 responden (12\%), lebih dari 10 tahun yaitu 54 responden $(78 \%)$, dan rata-rata usia yaitu 17 tahun. Jumlah responden yang tidak merokok adalah 7 responden (10\%).

Berdasarkan faktor okupasi atau pekerjaan, sebanyak 14 responden (21\%) melakukan aktivitas menyemprot 2 kali seminggu dan 55 responden (79\%) lebih dari 2 kali seminggu. Durasi penyemprotan yang kurang dari 4 jam per hari dilakukan oleh 43 responden $(62 \%)$, sedangkan yang lebih dari 4 jam per hari dilakukan oleh 26 responden (38\%). Ratarata nilai skor pajanan yang diperoleh dari hasil kuesioner adalah 15,2 dengan standar deviasi 1,8 . Nilai minimum skor pajanan yaitu 10 dan maksimal 18.

Sebagian responden, yaitu 24 orang (35\%), mengalami gangguan kognitif ringan berdasarkan hasil kuesioner MMSE yang ditunjukkan pada hasil di Tabel 2 dengan skor minimum adalah 18 dan maksimal 23. Dua (2) orang (3\%) mengalami gangguan kognitif sedang dengan skor minimum adalah 16 dan maksimal 17. Tidak terdapat responden yang mengalami gangguan kognitif berat dalam penelitian ini, dan sebanyak 43 orang (62\%) tidak memiliki gangguan kognitif (normal).

Penilaian aktivitas AChE diperoleh dari perbandingan hasil AChE terhadap nilai hematokrit (Tabel 1), nilai AChE terendah adalah $1024 \mathrm{U} / 1$ dan tertinggi adalah 5265 U/1, rata-rata nilai AChE sebesar 2941,68 U/1 
Tabel 1 Karakteristik Responden

\begin{tabular}{|c|c|c|c|c|c|}
\hline Karakteristik & Jumlah (n) & $(\%)$ & Rata-Rata & (Min-Maks) & Satuan \\
\hline \multicolumn{6}{|l|}{ Tingkat Pendidikan } \\
\hline Rendah (SD) & 38 & 55 & & & \\
\hline Menengah (SMP-SMA) & 31 & 45 & & & \\
\hline \multicolumn{6}{|l|}{ Kebiasaan Merokok } \\
\hline Tidak Merokok & 7 & 10 & 17 & $(3-50)$ & Tahun \\
\hline Merokok $<10$ Tahun & 8 & 12 & & & \\
\hline Merokok $>10$ Tahun & 54 & 78 & & & \\
\hline \multicolumn{6}{|l|}{ Faktor Okupasi } \\
\hline \multicolumn{6}{|l|}{ Frekuensi Penyemprotan } \\
\hline$<2 \mathrm{x}$ seminggu & 14 & 21 & & & \\
\hline$>2 \mathrm{x}$ seminggu & 55 & 79 & & & \\
\hline \multicolumn{6}{|l|}{ Durasi Penyemprotan } \\
\hline$<4$ jam per hari & 43 & 62 & & & \\
\hline$>4$ jam per hari & 26 & 38 & & & \\
\hline \multicolumn{6}{|l|}{ Penggunaan APD } \\
\hline Ya & 14 & 21 & & & \\
\hline Tidak & 55 & 79 & & & \\
\hline Usia & & & 42 & $(21-59)$ & Tahun \\
\hline Masa Kerja & & & 17 & $(1-37)$ & Tahun \\
\hline Skor Pajanan Pestisida & & & 15 & $(10-18)$ & \\
\hline \multicolumn{6}{|l|}{ Indeks Massa Tubuh } \\
\hline Non-obese $(\leq 24,99)$ & 58 & 84 & 21,49 & $(15,00-33,30)$ & \\
\hline Obese $(\geq 25,00)$ & 11 & 16 & & & \\
\hline Skor MMSE & & & 24 & $(16-30)$ & \\
\hline Nilai AChE & & & 2941 & $(1024-5265)$ & $\mathrm{U} / 1$ \\
\hline Nilai Hematokrit & & & 465 & $(308-548)$ & $\mathrm{g} / \mathrm{l}$ \\
\hline Aktivitas AChE & & & 6.38 & $(2.31-10,62)$ & U/g Hematokrit \\
\hline Total & 69 & 100 & & & \\
\hline \multicolumn{6}{|c|}{$\begin{array}{l}\text { Keterangan: Min=Minimum; Maks=Maksimum; SD=Sekolah Dasar; SMP }=\text { Sekolah Menengah Pertama; SMA=Sekolah } \\
\text { Menengah Atas; APD=Alat Pelindung Diri; MMSE }=\text { Mini Mental State Examination } ; \mathrm{AChE}=\text { Enzim asetilkolinesterase }\end{array}$} \\
\hline \multicolumn{3}{|c|}{$\begin{array}{l}\text { dengan standar deviasi sebesar } 996,59 . \text { Pada } \\
\text { hematokrit, nilai terendahnya yaitu sebesar } \\
308 \mathrm{~g} / 1 \text { dan nilai tertinggi sebesar } 548 \mathrm{~g} / 1 \text {, } \\
\text { rata-ata nilai hematokrit adalah } 465,46 \mathrm{~g} / 1 \\
\text { dengan standar deviasi sebesar } 36,76 . \text { Dari } \\
\text { data yang diperoleh tersebut, dapat diketahui }\end{array}$} & \multicolumn{3}{|c|}{$\begin{array}{l}\text { nilai rata-rata aktivitas } \mathrm{AChE} \text { adalah } 6,38 \\
\mathrm{U} / \mathrm{g} \text { hematokrit dengan standar deviasinya } \\
\text { sebesar 2,25. Nilai minimum AChE yang } \\
\text { diperoleh yakni sebesar 2,31 U/g hematokrit } \\
\text { dan nilai maksimum AChE sebesar } 10,62 \\
\mathrm{U} / \mathrm{g} \text { hematokrit. }\end{array}$} \\
\hline \multicolumn{2}{|c|}{ Kategori Fungsi Kognitif } & \multicolumn{2}{|c|}{ Jumlah (n) } & \multicolumn{2}{|c|}{ Persentase (\%) } \\
\hline \multicolumn{2}{|c|}{ Tidak ada gangguan kognitif (skor 24-30) } & \multicolumn{2}{|r|}{43} & \multicolumn{2}{|r|}{62} \\
\hline \multicolumn{2}{|c|}{ Gangguan kognitif ringan (skor 18-23) } & \multicolumn{2}{|r|}{24} & \multicolumn{2}{|r|}{35} \\
\hline \multicolumn{2}{|c|}{ Gangguan kognitif sedang (skor 11-17) } & \multicolumn{2}{|r|}{2} & \multicolumn{2}{|r|}{3} \\
\hline \multicolumn{2}{|c|}{ Gangguan kognitif berat (skor 0-10) } & \multicolumn{2}{|r|}{0} & \multicolumn{2}{|r|}{0} \\
\hline \multicolumn{2}{|l|}{ Total } & \multicolumn{2}{|r|}{69} & & 100 \\
\hline
\end{tabular}


Tabel 3 Hasil Analisis Bivariat Faktor Risiko Terhadap Fungsi Kognitif

\begin{tabular}{|c|c|c|c|}
\hline Karakteristik & $\begin{array}{c}\text { Fungsi Kognitif Normal } \\
\text { n (\%) }\end{array}$ & $\begin{array}{c}\text { Gangguan Fungsi Kognitif } \\
\text { n ( } \%)\end{array}$ & p \\
\hline \multicolumn{4}{|l|}{ Usia } \\
\hline$<45$ tahun & $27(39)$ & $7(11)$ & $0.016^{*}$ \\
\hline$>45$ tahun & $16(23)$ & $19(27)$ & \\
\hline \multicolumn{4}{|l|}{ Masa Kerja } \\
\hline$<10$ tahun & $15(22)$ & $5(7)$ & 0.408 \\
\hline$>10$ tahun & $28(41)$ & $21(30)$ & \\
\hline \multicolumn{4}{|l|}{ Tingkat Pendidikan } \\
\hline Rendah (SD) & $16(23)$ & $22(39)$ & $0.001 *$ \\
\hline Menengah (SMP-SMA) & $27(87)$ & $4(6)$ & \\
\hline \multicolumn{4}{|l|}{ Indeks Massa Tubuh } \\
\hline Non-obese $(\leq 24,99)$ & $33(49)$ & $25(36)$ & $0.033^{*}$ \\
\hline Obese $(\geq 25,00)$ & $10(14)$ & $1(1)$ & \\
\hline \multicolumn{4}{|l|}{ Kebiasaan Merokok } \\
\hline Tidak Merokok & $3(4)$ & $4(5)$ & 0.837 \\
\hline Merokok $<10$ tahun & $6(9)$ & $2(2)$ & \\
\hline Merokok $>10$ tahun & $34(49)$ & $20(31)$ & \\
\hline \multicolumn{4}{|l|}{ Faktor Okupasi } \\
\hline Frekuensi Penyemprotan & $8(11)$ & $6(9)$ & 0.66 \\
\hline$<2 \mathrm{x}$ seminggu & $35(51)$ & $20(29)$ & \\
\hline$>2 x$ seminggu & & & \\
\hline \multicolumn{4}{|l|}{ Durasi Penyemprotan } \\
\hline$<4$ jam per hari & $31(45)$ & $12(17)$ & $0.031 *$ \\
\hline$>4$ jam per hari & $12(17)$ & $14(21)$ & \\
\hline \multicolumn{4}{|l|}{ Penggunaan APD } \\
\hline $\mathrm{Ya}$ & $11(16)$ & $3(4)$ & 0.165 \\
\hline Tidak & $32(47$ & $23(33)$ & \\
\hline
\end{tabular}

\section{Pembahasan}

Perhitungan statistik melalui analisis bivariat dilakukan untuk melihat hubungan antara faktor risiko sebagai variabel bebas dengan fungsi kognitif sebagai variabel terikat dengan menggunakan aplikasi SPSS versi 25. Karena data terdistribusi tidak normal dan terdiri dari data kategorik dan numerik, maka metode uji Spearman dilakukan pada analisa bivariat ini. Hasil perhitungan statistik secara analisis bivariat (Tabel 3) menunjukkan bahwa empat faktor risiko memiliki hubungan bermakna terhadap fungsi kognitif dengan nilai $p<0,05$, yaitu faktor usia $(\mathrm{p}=0,016)$, tingkat pendidikan $(p=0,001)$, indeks massa tubuh $(p=0,033)$ dan durasi penyemprotan saat bekerja $(\mathrm{p}=0,031)$. Pada penelitian ini, fungsi kognitif dikelompokkan menjadi 2 kelompok yaitu fungsi kognitif normal dan gangguan fungsi kognitif. Kategori usia dibagi menjadi usia di atas 45 tahun dan di bawah 45 tahun, yang dilakukan dengan mempertimbangkan bahwa fungsi kognitif mulai mengalami penurunan sejak usia 45 tahun, dan hal ini dibuktikan oleh penelitian yang dilakukan oleh Manoux tahun 2012 secara kohort yang menunjukkan bahwa 3,6\% laki-laki akan mengalami penurunan fungsi kognitif pada usia 45-49 tahun. Pada kategori durasi penyemprotan, pengelompokan dilakukan berdasar pada waktu penyemprotan yaitu lebih dari 4 jam dan kurang dari 4 jam. $^{7}$ 
Tabel 4 Hasil Analisis Multivariat Faktor Okupasi Terhadap Fungsi Kognitif

\begin{tabular}{lccc}
\hline \multicolumn{1}{c}{ Karakteristik } & Nilai-p & Exp (B) & CI95\% \\
\hline Usia & $0.010^{*}$ & 5.6 & $1.5-21.1$ \\
Pendidikan & $0.002^{*}$ & 0.1 & $0.03-0.47$ \\
Durasi Penyemprotan & $0.016^{*}$ & 4.9 & $1.3-18.1$ \\
\hline
\end{tabular}

Keterangan: $\mathrm{CI}=$ Confidence Interval

Hasil statistik analisis multivariat (Tabel 4) menunjukkan bahwa faktor usia memiliki nilai $\mathrm{p}<0,05$ yaitu $\mathrm{p}=0,010$ dengan nilai Odds Ratio (OR) (Confidence Interval/ CI 95\%) sebesar 5,6 (1,5-21,1), sehingga dapat dikatakan bahwa pekerja perkebunan yang berusia di atas 45 tahun lebih berisiko mengalami gangguan fungsi kognitif 5,6 kali dibanding pekerja yang berusia di bawah 45 tahun. Selain itu, batasan usia 45 tahun juga memiliki keterkaitan dengan dampak pajanan pestisida yang dapat diterima seseorang. The Agricultural Health Study di Amerika Serikat melansir bahwa pekerja di bawah 45 tahun memiliki risiko 2 kali lipat lebih besar untuk mendapatkan pajanan pestisida dalam dosis lebih tinggi jika dibandingkan pekerja di atas 45 tahun. Hal tersebut mungkin berkaitan dengan produktivitas yang lebih tinggi pada usia yang lebih muda, sehingga frekuensi dan intensitas pajanan pun lebih tinggi. ${ }^{7}$

Penurunan fungsi kognitif dapat terjadi karena faktor usia. Seiring dengan usia yang meningkat, akan diikuti dengan perubahan dan penurunan fungsi anatomi seperti perubahan biokimiawi di sistem saraf pusat dan semakin menyusutnya otak. ${ }^{8}$ Berkurangnya berbagai cadangan homeostatik akan berimbas pada gangguan fungsi kognitif, contohnya seperti penurunan asupan glukosa dan oksigen yang sejatinya merupakan sumber nutrisi utama metabolisme otak yang dapat menyebabkan terganggunya jalur metabolik di otak. ${ }^{8}$

Berdasarkan hasil pada Tabel 4, faktor okupasi durasi penyemprotan memiliki nilai $\mathrm{p}=0,016$ dengan nilai OR (CI 95\%) 4,9 (1,318,1). Dari analisis statistik, dapat dikatakan bahwa pekerja perkebunan yang melakukan durasi penyemprotan lebih dari 4 jam per hari berisiko 4,9 kali mengalami gangguan fungsi kognitif dibanding pekerja yang melakukan durasi penyemprotan kurang dari atau di bawah 4 jam per hari. Hal ini dapat disebabkan semakin lama durasi penyemprotan maka dampak kumulatif pajanan yang dihasilkan juga semakin besar, sehingga memengaruhi fungsi kognitif. ${ }^{9}$

Faktor tingkat pendidikan, walaupun tidak signifikan, namun memiliki hubungan yang bermakna dengan fungsi kognitif, yaitu tingkat pendidikan memiliki hubungan yang erat dengan tingkat pengetahuan. Kedua aspek tersebut merupakan aspek yang akan menentukan sikap seseorang. ${ }^{10}$ Pengetahuan dapat diperoleh dari pendidikan formal dan nonformal. Petani yang memiliki pengetahuan akan bahaya pestisida dapat meminimalisasi risiko penyakit akibat kerja. Di lain pihak, kurangnya pengetahuan mengenai bahaya pestisida dapat berpengaruh pada perilaku atau praktik yang kurang tepat pula. ${ }^{10}$

Selain hubungan faktor okupasi terhadap

Tabel 5 Hasil Analisis Multivariat Faktor Okupasi Terhadap Aktivitas AChE

\begin{tabular}{lccc}
\hline \multicolumn{1}{c}{ Karakteristik } & Nilai-p & Exp (B) & CI95\% \\
\hline Pendidikan & $0,044^{*}$ & 3,3 & $1,0-10,4$ \\
Frekuensi Penyemprotan & $0,035^{*}$ & 0,22 & $0,05-0,89$ \\
Penggunaan APD & $0,011^{*}$ & 7,3 & $1,6-34,2$ \\
\hline Keterangan: AChE= Enzim asetilkolinesterase; CI=Confidence Interval & &
\end{tabular}


fungsi kognitif, analisis multivariat juga dilakukan untuk mengetahui faktor okupasi yang ada terhadap aktivitas AChE. Aktivitas AChE dikelompokkan dengan berdasarkan nilai median atau cut off 6,5. Aktivitas AChE di atas nilai tersebut dikategorikan sebagai normal, sedangkan di bawah angka tersebut dikategorikan menurun. Di Indonesia, belum terdapat penelitian yang mengukur aktivitas AChE eritrosit sehingga belum didapatkan rujukan serupa.

Hasil statistik pada Tabel 5 menunjukkan terdapat tiga faktor okupasi yang memiliki hubungan bermakna terhadap aktivitas $\mathrm{AChE}$ $(p<0,05)$, yaitu faktor tingkat pendidikan $(\mathrm{p}=0,044)$, faktor frekuensi penyemprotan $(\mathrm{p}=0,035)$, dan penggunaan Alat Pelindung Diri (APD) $(p=0,011)$. Pada hasil statistik tersebut, dapat dikatakan bahwa responden atau pekerja perkebunan yang mempunyai gangguan fungsi kognitif dengan tingkat pendidikan yang lebih rendah berisiko 3,3 kali mengalami penurunan aktivitas $\mathrm{AChE}$, dan responden atau pekerja perkebunan yang tidak menggunakan APD berisiko 7,3 kali mengalami penurunan aktivitas AChE. Hal ini didukung oleh jawaban kuesioner hasil wawancara petani yang mengungkap bahwa beberapa petani merasa terganggu dengan penggunaan APD, khususnya masker dan kacamata, sehingga para petani jarang sekali menggunakan APD yang lengkap bahkan ada yang tidak menggunakan APD sama sekali. Hal tersebut mengakibatkan pajanan pestisida akan terakumulasi dan dapat memengaruhi aktivitas AChE pada pekerja.

Penelitian yang dilakukan Maria, et al. (2013) pada pekerja di Denpasar menunjukkan adanya hubungan antara pengetahuan dan pendidikan para pekerja terhadap pemakaian APD $(p=0,023)$, dan antara pengetahuan dan pendidikan memiliki hubungan yang sangat signifikan $(p=0,000) .{ }^{11}$ Hasil penelitian yang dilakukan oleh tim peneliti sejalan dengan hasil penelitian Budiawan (2013) pada petani bawang merah di Pati yang menggunakan pestisida organofosfat; ditemukan adanya hubungan yang bermakna antara frekuensi penyemprotan $(p=0,011)$, pemakaian APD $(\mathrm{p}=0,047)$ dan pendidikan atau pengetahuan $(\mathrm{p}=0,020)$ terhadap aktivitas AChE. ${ }^{12}$

Jika para petani melakukan penyemprotan dengan jangka waktu yang lama, pestisida yang menempel dalam tubuh akan semakin meningkat pula sehingga terjadi pengikatan kolinesterase darah oleh pestisida tersebut apabila tidak segera dilakukan pencegahan atau pencucian setelah beraktivitas dengan pestisida organofosfat. ${ }^{13}$ Perilaku atau sikap petani yang tidak menggunakan APD pada saat melakukan aktivitas menyemprot dan tidak mengganti pakaian setelahnya, dapat menurunkan aktivitas AChE sebesar 939,049 U/L jika dilakukan penyemprotan selama satu jam. Oleh karena itu, durasi penyemprotan tidak diperkenankan melewati satu jam per minggu, sebab apabila dibandingkan dengan kadar normal AChE sekitar 3.500 U/L, maka telah terjadi penurunan lebih dari $25 \%$. $^{12,13}$

Hasil studi yang dilakukan oleh Singh, et al. (2012) selama 10 tahun sejalan dengan hasil yang diperoleh pada penelitian ini, yaitu indeks massa tubuh memiliki hubungan bermakna dengan fungsi kognitif, yaitu pada subjek yang mengalami obesitas menunjukkan penurunan yang signifikan terhadap fungsi kognitifnya. ${ }^{14}$ Mekanisme dalam tubuh yang kemungkinan mendukung adanya hubungan obesitas dengan penyakit Alzheimer ditandai dengan menurunnya fungsi kognitif antara lain hormon turunan adiposit (adipokin dan sitokin), advanced glycosylation products, hiperinsulinemia, pengaruh lemak pada risiko penyakit vaskular dan serebrovaskular. ${ }^{15}$

Fungsi kognitif merupakan proses yang kompleks dengan melibatkan berbagai faktor pada setiap individu antara lain usia, genetik, riwayat trauma kepala, tingkat pendidikan, lingkungan (seperti keracunan logam berat), kadar kolesterol dan lipid, status gizi, fungsi 
tiroid, penyakit vaskular, serta gangguan immunitas. Namun, beberapa hal tersebut tidak terwakili dalam penelitian ini sehingga menjadi keterbatasan dalam penelitian ini, dan oleh sebab itu hasilnya pun akan berbedabeda pada setiap individu. ${ }^{16,17}$

\section{Simpulan}

Terdapat hubungan yang bermakna antara faktor okupasi terhadap aktivitas enzim asetilkolinesterase (AChE) eritrosit yaitu pada faktor tingkat pendidikan, faktor frekuensi penyemprotan, dan faktor penggunaan Alat Pelindung Diri (APD). Terdapat hubungan yang bermakna antara faktor okupasi terhadap fungsi kognitif, tingkat pendidikan, indeks massa tubuh, dan durasi penyemprotan. Hasil analisis secara statistik menunjukkan bahwa petani yang berusia di atas 45 tahun lebih berisiko mengalami gangguan fungsi kognitif 5,6 kali dibandingkan petani yang berusia di bawah 45 tahun. Petani yang melakukan durasi penyemprotan selama lebih dari 4 jam per hari berisiko 4,9 kali mengalami gangguan fungsi kognitif dibandingkan petani dengan durasi penyemprotan kurang dari atau di bawah 4 jam per hari. Selain itu, hasil analisis multivariat menunjukkan bahwa petani yang memiliki gangguan fungsi kognitif dengan tingkat pendidikan lebih rendah berisiko 3,3 kali mengalami penurunan aktivitas AChE, dan petani yang tidak memakai APD berisiko 7,3 kali mengalami penurunan aktivitas $\mathrm{AChE}$.

\section{Ucapan Terima Kasih}

Terima kasih kepada PT. Prodia Widyahusada, Tbk. yang telah membantu proses analisis sampel dalam penelitian ini.

\section{Pendanaan}

Penelitian ini memperoleh bantuan pendanaan dari PT. Prodia Widyahusada, Tbk.

\section{Konflik Kepentingan}

Seluruh penulis menyatakan tidak terdapat potensi konflik kepentingan dengan penelitian, kepenulisan (authorship), dan atau publikasi artikel ini.

\section{Daftar Pustaka}

1. Achmadi UF. Upaya kesehatan kerja sektor informal di Indonesia. Jakarta: Departemen Kesehatan Republik Indonesia; 2013.

2. Assis CRD, Linhares AG, Cabrera MP, Oliveira VM, Silva KCC, Marcuschi M, et al. Erythrocyte acetylcholinesterase as biomarker of pesticide exposure: New and forgotten insights. Environ Sci Pollut Res Int. 2018;25(19):18364-76. doi: 10.1007 /s11356-018-2303-9

3. Neal MJ. Medical pharmacology at a glance. United States: Wiley-Blackwell; 2013.

4. der Heide EA. Cholinesterase inhibitors: Including pesticides and chemical warfare nerve agents; 2012 [Diunduh 6 Juni 2019]. Tersedia dari: https://www.atsdr.cdc.gov/c sem/csem.asp?csem $=11 \&$ po $=2$

5. Todd M, Schneper L, Vasunilashorn SM, Notterman D, Ullman MT, Goldman N. Apolipoprotein E, cognitive function, and cognitive decline among older Taiwanese adults. Plos One. 2018;13(10): e0206118. doi: 10.1371/journal.pone.0206118

6. Cinthya Y. Hubungan aktivitas asetilkolinesterase dalam sel darah merah terhadap fungsi kognitif pada laki-laki petani bunga penyemprot pestisida (tesis). Jakarta: Universitas Indonesia; 2019.

7. Manoux AS. Cognitive decline can begin as early as age 45, warn experts. 2012 [Diunduh 6 Juni 2019]. Tersedia dari: https:// www.bmj.com/press-releases/2012/01/05/ cognitive-decline-can-begin-early-age-45warn-experts

8. Johansson M. Cognitive impairment 
and its consequences in everyday life (disertasi). Swedia: Linkoping University. 2015

9. Sri W, Indratin, Asep NA. Kontaminasi residu organofosfat dalam darah petani padi di Kabupaten Indramayu Jawa Barat. Prosiding Workshop dan International: Inovasi Pestisida Ramah Lingkungan Mendukung Swasembada Pangan; 2017 September 6-7: Pati, Indonesia. Indonesia: Balai Penelitian dan Pengembangan Pertanian; 2017.

10. Yuantari MGC, Widiarnoko B, Sunoko HR. Tingkat pengetahuan petani dalam menggunakan pestisida (studi kasus di Desa Curut Kecamatan Penawangan Kabupaten Grobogan). Prosiding Seminar Nasional Pengelolan Sumber Daya Alam dan Lingkungan; 2013 September 10: Semarang, Indonesia. Indonesia: Universitas Dipenogoro; 2013.

11. Dhema MT, Sal IW, Darmadi IGW. Hubungan tingkat pengetahuan dan pendidikan pekerja terhadap penggunaan alat pelindung diri di Perusahaan Kayu Kembang Jaro Desa Sidakarya Denpasar Selatan. Jurnal Kesehatan Lingkungan. 2014; 4(1):57-60.

12. Budiawan AR. Faktor risiko cholinesterase rendah pada petani bawang merah. Kemas.
2013;8(2):198-206. doi: 10.15294/kemas .v8i2.2822

13. Gusti A, Desnizar I. Faktor-faktor yang berhubungan dengan gejala neurotoksik pada petani penyemprot tanaman sayuran dengan pestisida di Kenagarian Alahan Panjang Kabupaten Solok. J Kesehatan Lingkungan Indonesia. 2016;16(1):17-21. doi: $10.14710 /$ jkli.16.1.17-21

14. Singh-Manoux A, Czernichow S, Elbaz A, Dugravot A, Sabia S, Hagger-Johnson $\mathrm{G}$, et al. Obesity phenotypes in midlife and cognition in early old age: The Whitehall II cohort study. Neurology. 2012;79(8):755-62. doi: 10.1212/WNL.0 b013e3182661f63

15. Luchsinger JA, Patel B, Tang MX, Schupf N, Mayeux R. Measures of adiposity and dementia risk in elderly persons. Arch Neurol. 2007;64(3):392-8. doi: 10.1001/ archneur.64.3.392

16. Jett DA. Neurotoxic pesticides and neurologic effects. Neurol Clin. 2011;29 (3):667-77. doi: 10.1016/j.ncl.2011.06.002

17. Wahid BDJ, Sudarma V. Hubungan status gizi dan penurunan fungsi kognitif pada lansia. Prosiding Seminar Nasional Pakar; 2018 Maret 1: Jakarta, Indonesia. Indonesia: Universitas Trisakti; 2018. 